\title{
Deconstructions
}


From the same publishers

The Feminist Reader Edited by Catherine Belsey and Jane Moore

New Historicism and Cultural Materialism John Brannigan

Postmodern Narrative Theory Mark Currie

Literary Theory from Plato to Barthes Richard Harland

Marxist Literary and Cultural Studies Moyra Haslett

Renaissance Drama and Contemporary Literary Theory Andy Mousley

Twentieth-Century Literary Theory K. M. Newton

Literary Feminisms Ruth Robbins

Deconstruction - Derrida Julian Wolfreys

Literary Theories Edited by Julian Wolfreys and William Baker

Applying: To Derrida Edited by John Brannigan, Ruth Robbins and Julian Wolfreys 


\title{
Deconstructions
}

\section{A User's Guide}

\author{
Edited by \\ Nicholas Royle
}




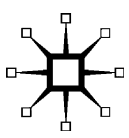

Selection, editorial matter and Chapter 1 @ Nicholas Royle 2000. Individual chapters @ individual contributors 2000

All rights reserved. No reproduction, copy or transmission of this publication may be made without written permission.

No paragraph of this publication may be reproduced, copied or transmitted save with written permission or in accordance with the provisions of the Copyright, Designs and Patents Act 1988, or under the terms of any licence permitting limited copying issued by the Copyright Licensing Agency, 90 Tottenham Court Road, London W1P 0LP.

Any person who does any unauthorised act in relation to this publication may be liable to criminal prosecution and civil claims for damages.

The authors have asserted their rights to be identified as the authors of this work in accordance with the Copyright, Designs and Patents Act 1988.

First published 2000 by

PALGRAVE

Houndmills, Basingstoke, Hampshire RG21 6XS and

175 Fifth Avenue, New York, N.Y. 10010

Companies and representatives throughout the world

PALGRAVE is the new global academic imprint of St. Martin's Press LLC Scholarly and Reference Division and Palgrave Publishers Ltd (formerly Macmillan Press Ltd).

ISBN 978-0-333-71760-8 hardback

ISBN 978-0-333-71761-5 ISBN 978-1-137-06095-2 (eBook) DOI 10.1007/978-1-137-06095-2

This book is printed on paper suitable for recycling and made from fully managed and sustained forest sources.

A catalogue record for this book is available from the British Library.

Library of Congress Cataloging-in-Publication Data

Deconstructions : a user's guide / edited by Nicholas Royle. p. cm.

Includes bibliographical references and index.

ISBN 978-0-333-71760-8-ISBN 978-0-333-71761-5 (pbk.)

1. Deconstruction. I. Royle, Nicholas, 1963PN98.D43 D424 2000

149 -dc21

00-059130

$\begin{array}{llllllllll}10 & 9 & 8 & 7 & 6 & 5 & 4 & 3 & 2 & 1\end{array}$

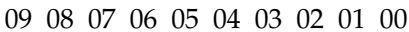




\section{Contents}

Preface vii

Acknowledgements viii

Notes on the Contributors ix

1 What is Deconstruction? Nicholas Royle 1

2 Deconstruction and Cultural Studies: Arguments for a Deconstructive Cultural Studies Gayatri Chakravorty Spivak 14

3 Deconstruction and Drugs: A Philosophical/Literary Cocktail David Boothroyd

4 Deconstruction and Ethics Geoffrey Bennington 64

5 Deconstruction and Feminism Diane Elam 83

6 Deconstruction and Fiction Derek Attridge 105

7 Deconstruction and Film Robert Smith 119

8 Deconstruction and Hermeneutics Rodolphe Gasché 137

9 Deconstruction and Love Peggy Kamuf 151

10 Deconstruction and a Poem J. Hillis Miller 171

11 Deconstruction and the Postcolonial Robert J. C. Young 187

12 Deconstruction and Psychoanalysis Maud Ellmann 211

13 Deconstruction and Technology Timothy Clark 238

14 Deconstruction and Weaving Caroline Rooney 258

15 Et Cetera Jacques Derrida 282

$\begin{array}{ll}\text { Index } & 306\end{array}$ 


\section{Preface}

This book is intended as a user's guide to deconstruction across a range of topics and discourses. There are essays on cultural studies, drugs, ethics, feminism, fiction, film, hermeneutics, love, poetry, postcolonialism, psychoanalysis, technology and weaving. But each of these essays has more than one focus, exploring or opening onto further and other deconstructions. The chapter on feminism, for example, is in a sense just as much, also, about visual art; the chapter on fiction as much, also, about confession; the chapter on the postcolonial as much, also, about the Jewish-Algerian-French 'origins' of deconstruction. And so on. Deconstructions has been put together in the hope of demonstrating the ceaselessly multiple and altering contexts in which deconstructive thinking and practice are at work, both within and beyond the academy, both within and beyond what is called 'the West'. The book starts with an introductory piece, 'What is Deconstruction?', before moving on to a series of more specifically focused essays, each of them specially written for this volume. It was proposed at the outset of this project that each essay should have a title beginning 'deconstruction and .... The final essay, by Jacques Derrida, is concerned with the 'and' itself. As he remarks at the beginning of that essay, in the beginning there is the 'and'. Inaugural and supplementary, 'and' affirms the irreducible opening of, and to, deconstructions. The index at the end of the book suggests, under the heading 'deconstruction and ...', at least some of its innumerable other possibilities. 


\section{Acknowledgements}

The editor and publishers would like to thank Jenny Holzer for permission to reproduce four of her works:

Raise Boys and Girls the Same Way, from Truisms (Sony JumboTRON video sign, Candlestick Park, San Francisco, 1987);

Arno, nine LED signs (Museo Guggenheim, Bilbao);

I Am Awake in the Place Where Women Die, from Lustmord; photograph of handwriting on skin;

With You Inside Me Comes the Knowledge of My Death, from Lustmord; human bone and engraved and etched silver (Galerie Rähnitzgasse der Landeschauptstadt, Dresden, 1996).

The editor would also like to thank Pauline Morgan for her help with compiling the index, and Maxwell Royle for his help with proofreading. 


\section{Notes on the Contributors}

Derek Attridge is Leverhulme Research Professor at the University of York. He is the editor of Jacques Derrida's Acts of Literature (1992) and the author or editor of several books on poetics, deconstruction, James Joyce, and South African literature.

Geoffrey Bennington is Professor of French at the University of Sussex, where he is also Director of the Centre for Modern French Thought. He has written extensively on the work of Jacques Derrida, and his books include Jacques Derrida (1991) (written with Derrida himself) and Interrupting Derrida (2000).

David Boothroyd teaches cultural studies at the University of Teesside. He is a co-founding director of Culture Machine (http://culturemachine.tees.ac.uk) and his work in cultural theory and philosophy has appeared in several edited collections and scholarly journals. His forthcoming book is entitled Culture on Drugs: Narco-Cultural Studies of High Modernity.

Timothy Clark teaches at the University of Durham. He works in literary theory, especially Romantic and post-Heideggerian poetics. His books include Derrida, Heidegger, Blanchot (1992) and The Theory of Inspiration (1997). He is currently working on a study of Heidegger's poetics, and he is co-editor of the Oxford Literary Review.

Jacques Derrida has for more than thirty-five years been one of the most faithful users of 'deconstructions'. But he is not and has never wished to be - nor even to supply - a guide to them.

Diane Elam is Professor of English Literature and Critical and Cultural Theory at Cardiff University. She is the author of Feminism and Deconstruction: Ms en Abyme (1994) and Romancing the Postmodern (1992), as well as co-editor with Robyn Wiegman of Feminism Beside Itself (1995).

Maud Ellmann is University Lecturer and Fellow in English at King's 
College, Cambridge. She is the author of The Hunger Artists: Starving, Writing and Imprisonment (1993) and editor of Psychoanalytic Literary Criticism (1994).

Rodolphe Gasché is Eugenio Donato Professor of Comparative Literature at the State University of New York at Buffalo. His books include Die hybride Wissenschaft (1973), System und Metaphorik in der Philosophie von Georges Bataille (1978), The Tain of the Mirror: Derrida and the Philosophy of Reflection (1986), Inventions of Difference: On Jacques Derrida (1994), The Wild Card of Reading: On Paul de Man (1998) and, most recently, Of Minimal Things: Studies on the Notion of Relation (1999). He is currently completing a booklength study on Kant's aesthetics.

Peggy Kamuf is Professor of French and Comparative Literature at the University of Southern California (Los Angeles). Her most recent book is The Division of Literature, or the University in Deconstruction (1997). She has translated numerous books and essays by Derrida, and is the editor of A Derrida Reader: Between the Blinds (1992).

J. Hillis Miller is UCI Distinguished Professor of English and Comparative Literature at the University of California, Irvine. He is the author of many books and articles on nineteenth- and twentieth-century literature and on literary theory. His most recent books are Reading Narrative (1998) and Black Holes (1999).

Caroline Rooney is Lecturer in English and a member of the Centre for Colonial and Postcolonial Research at the University of Kent. Her forthcoming book is entitled Literature, Animism and Politics.

Nicholas Royle is Professor of English at the University of Sussex. His books include Telepathy and Literature (1991), After Derrida (1995), The Uncanny (forthcoming), and (with Andrew Bennett) An Introduction to Literature, Criticism and Theory (2nd edition, 1999). He is co-editor of the Oxford Literary Review.

Robert Smith used to be a Prize Fellow of All Souls College, Oxford. During that period (1990-98) he published several texts exploring other texts - by Freud, Pascal, Wim Wenders, J. H. Prynne, Heidegger, etc. including a book on Derrida, Derrida and Autobiography (1995). He is executive editor of the journal Angelaki, as well as series editor of the Angelaki book series called Angelaki Humanities. Currently, he is completing a book under the working title of Remains Unknown: Forms of Death in Literature, Freud and Philosophy. 
Gayatri Chakravorty Spivak is Avalon Foundation Professor of the Humanities at Columbia University. Her books are Myself Must I Remake (1974), In Other Worlds (1987), The Post-Colonial Critic (1988), Outside in the Teaching Machine (1993), A Critique of Postcolonial Reason (1999) and Red Thread (forthcoming). She has translated Jacques Derrida's of Grammatology (1978), and Mahasweta Devi's Imaginary Maps (1994), Breast Stories (1997) and Old Women (1999).

Robert J. C. Young is Professor of English and Critical Theory at Oxford University and a Fellow of Wadham College. He is the author of White Mythologies: Writing History and the West (1990), Colonial Desire: Hybridity in Culture, Theory and Race (1995), Torn Halves: Political Conflict in Literary and Cultural Theory (1996), and Postcolonialism: An Historical Introduction (2000). He is also General Editor of Interventions: International Journal of Postcolonial Studies. 